\title{
PERAN IMPOSTOR SYNDROME DALAM MENJELASKAN KECEMASAN AKADEMIS PADA MAHASISWA BARU
}

\author{
Endah Suryaning Ati, Yunita Kurniawati, Ratri Nurwanti \\ endahsuryaningati@yahoo.co.id \\ Program Studi Psikologi Fakultas Ilmu Sosial dan Ilmu Politik \\ Universitas Brawijaya
}

\begin{abstract}
ABSTRAK
Penelitian ini bertujuan untuk mengetahui peran impostor syndrome dalam menjelaskan kecemasan akademis pada mahasiswa baru. Subyek penelitian $(\mathrm{N}=160)$ diperoleh melalui random sampling terhadap mahasiswa baru psikologi. Data diperoleh melalui Clance Impostor Phenomenon Scale (CIPS) yang terdiri dari 20 aitem dan State Trait Anxiety Inventory (STAI) yang terdiri dari 20 aitem untuk State Anxiety dan 20 aitem untuk Trait anxiety yang telah diadaptasi. Hasil penelitian menunjukkan 63 (39.35\%) subyek tergolong impostor dan 37 (23.15\%) subyek mengalami kecemasan akademis. Berdasarkan hasil penelitian diperoleh nilai $R$ square sebesar 0.175 jadi sumbangan efektif impostor syndrome terhadap kecemasan akademis pada mahasiswa baru sebesar $17.5 \%$ Berdasarkan hasil analisis regresi diperoleh nilai $F$ sebesar 33.582 dengan signifikansi sebesar $\mathrm{p}=0.0001$ $(\mathrm{p}<0.05)$ yang berarti terdapat pengaruh positif antara impostor syndrome dengan kecemasan akademis.
\end{abstract}

Kata kunci : impostor syndrome, kecemasan akademis, mahasiswa baru.

Mahasiswa baru merupakan salah satu kalangan akademis yang rentan terhadap tekanan psikis. Tekanan-tekanan tersebut muncul dikarenakan mereka mengalami perubahan peran dan lingkungan akademis. Saat mereka memasuki jenjang pendidikan di universitas, mahasiswa baru dihadapkan dengan proses belajar dan mengajar yang berbeda dengan lingkungan sekolah mereka yang dulu. Di lingkungan inilah mereka akan mengetahui berbagai kemampuan yang dimiliki oleh mahasiswa lain yang belum mereka ketahui. Pada tahap ini mahasiswa baru rentan terhadap kemampuan dirinya sendiri karena mereka membandingkan kemampuan yang mereka miliki tidak layak jika dibandingkan dengan mahasiswa yang lainnya.
Ketika mahasiswa baru merasa ragu terhadap kemampuannya, hal ini akan memicu suatu perasaan bersalah terhadap kesuksesan yang telah didapat. Clance \& Imes, (1978) menjelaskan kondisi ini sebagai suatu sindrom yang disebut dengan impostor syndrome. Impostor syndrome didefinisikan sebagai perasaan bersalah akan kesuksesan, kurangnya penerimaan terhadap keberhasilan, ketakutan akan evaluasi, perasaan tidak berharga dan perasaan ketidakmampuan pada pendidikan (Clance \& Imes, 1978; Clance \& O'Tool, 1998). Impostor syndrome terjadi pada mahasiswa baru dikarenakan oleh beberapa hal, diantaranya mereka belum akrab dengan peran atau posisi baru, daya saing antar mahasiswa, isolasi dalam jenjang 
pendidikan yang lebih tinggi, dan tekanan lain yang sering ditemukan dalam budaya akademik lainnya (Zorn,2005).

Impostor syndrome pertama kali diteliti oleh Clance dan Imes, dimana impostor syndrome digunakan untuk menggambarkan beberapa kalangan wanita dengan prestasi tinggi yang merasa seperti penipu akan prestasinya (Clance \& Imes, 1978). Meskipun studi awal impostor syndrome hanya ditujukan sebagai masalah yang terjadi di kalangan wanita yang berprestasi tinggi, penelitian selanjutnya menunjukkan bahwa pria juga mengalami perasaan impostor pada tingkat yang sebanding. Hal ini menggambarkan bahwa jenis kelamin bukan merupakan faktor yang berkontribusi terhadap munculnya impostor syndrome (Buchalter, 1992; Harvey,1981; Topping \& Kimmel, 1985; dalam Clark, Vardemen, \& Barba, 2014).

Clance dan Imes (1978) menyatakan bahwa sebagian besar klien mereka yang mengeluhkan perasaan sebagai impostor ketika mereka memasuki perubahan peran yang baru. Hasil penelitian yang dilakukan oleh Harvey (1981) menunjukkan hubungan korelasi antara skor impostor dengan jumlah tahun mahasiswa di sekolah (Chae, Piedmont, Estadt,\& Wicks, 1995). Hal tersebut juga didukung oleh hasil penelitian yang dilakukan oleh Chae, Piedmont, Estadt, dan Wicks (1995) terdapat korelasi yang negatif antara usia dan impostor syndrome. Maka mahasiswa yang berada pada tahun pertama memiliki perasaan sebagai impostor lebih tinggi dari pada siswa yang sudah berada pada tahun ke empat. Hal ini menunjukkan bahwa sebagian mahasiswa baru memiliki keraguan atau ketidakpercayaan terhadap kemampuan yang mereka miliki.
Individu dengan impostor syndrome merasa bahwa prestasi yang diraih sebenarnya bukan untuk mereka, sehingga penderita impostor syndrome cenderung khawatir bahwa mereka mungkin jadi terlihat seperti penipu. Dampaknya adalah, muncul perilaku maladaptif dan distress (Clance, 1985; Harvey \& Katz, 1985; Kolligian \& Strenberg, 1991; Sonak \& Towell, 2001; dalam Sakulku \& Alexander, 2011). Menurut Cowman dan Ferrari (Wulandari \& Tjundjing, 2007), individu dengan impostor syndrome dapat dikenali lewat karakteristik seperti mereka adalah orang-orang yang biasanya memulai pekerjaan lebih awal, akan tetapi proses penyelesainnya lama karena terlalu berlebihan dalam proses persiapan . Saat mereka meraih prestasi dalam tugasnya mereka menganggap bahwa itu hanya keberuntungan bukan dari kemampuan mereka. Perasaan takut akan kegagalan dan takut bahwa mereka akan dianggap sebagai seorang penipu oleh orang lain akan selalu ada.

Harvey (Sakulku \& Alexander, 2011) menyatakan bahwa setiap orang cenderung melihat diri mereka sendiri sebagai seorang penipu jika mereka gagal dalam menginternalisasikan keberhasilan mereka. Pengalaman ini tidak hanya terbatas pada orang yang sangat sukses . Semakin tinggi keberhasilan yang diraih oleh seorang individu, maka dapat menguatkan dan memicu terjadinya impostor syndrome didalam diri mereka. Perasaan yang biasa muncul dari seseorang dengan impostor syndrome bahwa mereka takut orang lain akan mengetahui kemampuan yang dimiliki tidak sesuai dengan yang ditunjukkannya.

Individu yang mengalami impostor syndrome biasanya memiliki keinginan 
kuat untuk terlihat pintar dalam bidang akademik, akan tetapi mereka justru mengalami ketakutan saat mengahadapi kesulitan dalam proses belajarnya (Langford \& Clance, 1993). Perasaanperasaan itu dapat menjadi stresor bagi individu tersebut. Saat individu mengalami perasaan sebagai seorang impostor, dan mereka tidak mampu mengatasinya maka hal tersebut juga dapat memicu munculnya suatu kecemasan. Chrisman dan Pieper (1995) menyatakan bahwa impostor syndrome memiliki hubungan erat dengan tingginya tingkat depresi dan kecemasan (Oriel, Plane, \& Mundt, 2004). Pengamatan klinis yang dilakukan oleh Clance (1985) mengungkapkan bahwa tingginya tingkat kecemasan, depresi, dan ketidakpuasan di kehidupannya, mendorong seorang impostor untuk mencari bantuan profesional (Sakulku \& Alexander, 2011).

Di kalangan mahasiswa bentuk kecemasan yang dapat muncul akibat impostor syndrome adalah kecemasan akademis. Ottens (1991) menjelaskan bahwa kecemasan akademis mengacu pada terganggunya pola pemikiran dan respon fisik serta perilaku karena kemungkinan performa yang ditampilkan siswa tidak diterima secara baik ketika tugas-tugas akademis diberikan. Ketika mahasiswa memiliki kecemasan, mereka akan mudah kehilangan konsentrasi, kurang percaya diri, memiliki daya nalar yang buruk, dan memori jangka pendek (Vitasari, Wahab, Othman, Herawan, \& Sinnadurai, 2010). Hal tersebut dapat mempengaruhi kinerja maupun performa dari mahasiswa tersebut. Dari situlah penulis merasa tertarik untuk melakukan penelitian mengenai impostor syndrome dan kecemasan akademis pada mahasiswa baru.

\section{METODE}

\section{Desain Penelitian}

Penelitian ini menggunakan jenis penelitian kuantitatif dengan metode korelasional, karena penelitian yang dilakukan untuk menghubungkan dan mengukur variabel impostor syndrome dengan variabel kecemasan akademis pada mahasiswa baru.

\section{Partisipan}

Populasi yang digunakan dalam penelitian ini adalah mahasiswa baru Fakultas Ilmu Sosial dan Ilmu Politik Universitas Brawijaya angkatan 2014. Sampel penelitian terdiri dari 160 mahasiswa Psikologi. Peneliti menggunakan teknik simple random sampling dalam menentukan sampel karena populasi penelitian bersifat homogen. Jadi peneliti menentukan sampel dengan cara mengundi berdasarkan program studi yang ada di Fakultas Ilmu Sosial dan Ilmu Politik yaitu prodi Ilmu Pemerintahan, Ilmu Politik, Ilmu Komunikasi, Hubungan Internasional, Sosiologi, dan Psikologi. Dari proses mengundi keluarlah nama program studi Psikologi yang digunakan dalam sampel penelitian ini.

\section{Instrumen Penelitian}

Instrumen dalam penelitian ini menggunakan skala Clance Impostor Phenomenon Scale (CIPS) dan State Trait Anxiety Inventory (STAI) yang telah diadaptasi oleh peneliti. CIPS terdiri dari 20 item untuk mengukur impostor syndrome dengan realibilitas sebesar 0.889. Selanjutnya penelitian ini menggunakan skala State Trait Anxiety Inventory (STAI) yang dikembangkan oleh Speilberger. STAI terdiri dari 40 item, 20 
item State Anxiety Inventory dan 20 item Trait Anxiety Inventory dengan nilai realibilitas 0.784 dan 0.789 . Untuk mengukur kecemasan akademis peneliti menggunakan STAI bagian State Anxiety Inventory.

\section{Analisis Data}

Teknik analisis data yang digunakan untuk pengujian hipotesis penelitian ini menggunakan analisis Regresi Sederhana menggunakan Program SPSS 16.0.

\section{HASIL}

\section{Hasil Analisis Deskriptif}

Tabel 1.

Deskripsi Data Variabel

\begin{tabular}{cccc}
\hline $\begin{array}{c}\text { Varia- } \\
\text { bel }\end{array}$ & Statistik & Hipotetik & $\begin{array}{c}\text { Empi- } \\
\text { rik }\end{array}$ \\
\hline $\begin{array}{c}\text { Impost- } \\
\text { or } \\
\begin{array}{c}\text { Syndro- } \\
\text { me }\end{array}\end{array}$ & $\begin{array}{c}\text { Skor } \\
\text { Minimum }\end{array}$ & 0 & 4 \\
& $\begin{array}{c}\text { Skor } \\
\text { Maksimum }\end{array}$ & 60 & 55 \\
& Mean & 30 & 31,32 \\
& $\begin{array}{c}\text { Standar } \\
\text { Deviasi }\end{array}$ & 10 & 9.647 \\
$\begin{array}{c}\text { Kece- } \\
\text { masan } \\
\text { Aka- } \\
\text { demis }\end{array}$ & $\begin{array}{c}\text { Skor } \\
\text { Minimum }\end{array}$ & 11 & 14 \\
& $\begin{array}{c}\text { Skor } \\
\text { Maksimum }\end{array}$ & 44 & 42 \\
& Mean & 27.5 & 27.14 \\
& $\begin{array}{l}\text { Standar } \\
\text { Deviasi }\end{array}$ & 5.5 & 5.012 \\
\hline
\end{tabular}

Pada tabel 1, terlihat bahwa untuk mean impostor syndrome, skor empirik lebih besar dari pada skor hipotetik hal tersebut menunjukkan bahwa level atau status impostor syndrome pada responden cenderung tinggi. Sedangkan nilai mean kecemasan akademis menunjukkan hasil yang seimbang antara skor empirik dan skor hipotetik. Jadi level atau status impostor syndrome dan kecemasan akademis tidak menunjukkan kecenderungan tinggi maupun rendah, karena nilai mean dari impostor syndrome dan kecemasan akademis yang diperoleh oleh subyek sama dengan nilai mean dari skala yang digunakan.

Berdasarkan pada tabel diatas diketahui bahwa standar deviasi dari impostor syndrome dan kecemasan akademin menunjukkan bahwa nilai skor empirik lebih rendah dari pada skor hipotetik sehingga skor impostor syndrome dan kecemasan akademis pada responden memiliki variasi yang rendah, jadi skor impostor syndrome dan kecemasan akademis pada responden tidak jauh berbeda atau hampir serupa.

\section{Kategorisasi}

Tabel 2

Kategori Impostor Syndrome

\begin{tabular}{|c|c|c|c|}
\hline Kategori & Norma & Jumlah & $\begin{array}{c}\text { Perse- } \\
\text { ntase }\end{array}$ \\
\hline Sangat & $X \leq 15$ & 8 & $5 \%$ \\
\hline \multicolumn{4}{|l|}{ Rendah } \\
\hline Rendah & $\begin{array}{c}15<\mathrm{X} \leq \\
25\end{array}$ & 30 & $\begin{array}{c}18.75 \\
\%\end{array}$ \\
\hline Sedang & $\begin{array}{c}25<\mathrm{X} \leq \\
35\end{array}$ & 59 & $36.9 \%$ \\
\hline Tinggi & $\begin{array}{c}35<\mathrm{X} \leq \\
45\end{array}$ & 54 & $\begin{array}{c}33.75 \\
\%\end{array}$ \\
\hline $\begin{array}{l}\text { Sangat } \\
\text { Tinggi }\end{array}$ & $45<X$ & 9 & $5.6 \%$ \\
\hline Total & & 160 & $100 \%$ \\
\hline
\end{tabular}

Berdasarkan tabel 2 dapat diketahui bahwa terdapat $54(33.75 \%)$ subyek berada dalam kategori tinggi, dan sembilan $(5.6 \%)$ subyek berada dalam kategori sangat tinggi. Sehingga dapat disimpulkan 
bahwa terdapat 63 subyek penelitian merupakan impostor syndrome dengan presentase sebesar $39.35 \%$ karena berada pada kategori tinggi dan sangat tinggi.

Tabel 3.

Kategori Kecemasan Akademis

\begin{tabular}{|c|c|c|c|}
\hline $\begin{array}{l}\text { Kate- } \\
\text { gori }\end{array}$ & Norma & Jumlah & $\begin{array}{c}\text { Persen- } \\
\text { tase }\end{array}$ \\
\hline $\begin{array}{l}\text { Sangat } \\
\text { Rendah }\end{array}$ & $X \leq 19$ & 8 & $5 \%$ \\
\hline Rendah & $\begin{array}{c}19<\mathrm{X} \leq \\
25\end{array}$ & 55 & $34.375 \%$ \\
\hline Sedang & $\begin{array}{c}25<\mathrm{X} \leq \\
30\end{array}$ & 60 & $37.5 \%$ \\
\hline Tinggi & $\begin{array}{c}30<\mathrm{X} \leq \\
36\end{array}$ & 30 & $18.75 \%$ \\
\hline $\begin{array}{l}\text { Sangat } \\
\text { Tinggi }\end{array}$ & $36<x$ & 7 & $4.375 \%$ \\
\hline Total & & 160 & $100 \%$ \\
\hline
\end{tabular}

Berdasarkan tabel 3 dapat diketahui bahwa 37 subyek mengalami kecemasan akademis dengan presentase sebesar $23.15 \%$. Hal tesebut dapat diketahui dari jumlah subyek yang berada dalam kategori tinggi sebanyak 30 (18.75\%) subyek dan kategori sangat tinggi sebanyak tujuh $(4.375 \%)$ subyek.

\section{Hasil Uji Normalitas dan Linieritas}

Uji asumsi yang digunakan dalam penelitian ini terdiri dari uji normalitas dan uji linieritas. Uji normalitas diuji dengan menggunakan One-Sample KolmogorovSmirnov.
Tabel 4

Hasil Uji Normalitas

\begin{tabular}{cccc}
\hline Variabel & $\begin{array}{c}\text { Kolmogorov- } \\
\text { Smirnov }\end{array}$ & $\begin{array}{c}\text { Signi- } \\
\text { fikansi }\end{array}$ & Ket. \\
\hline $\begin{array}{c}\text { Impostor } \\
\text { Syndrome }\end{array}$ & 0.074 & 0.033 & $\begin{array}{l}\text { Nor- } \\
\text { mal }\end{array}$ \\
$\begin{array}{c}\text { Kecema- } \\
\text { san }\end{array}$ & 0.070 & 0.056 & $\begin{array}{c}\text { Nor- } \\
\text { mal }\end{array}$ \\
$\begin{array}{c}\text { Akade- } \\
\text { mis }\end{array}$ & & & \\
\hline
\end{tabular}

Dilihat pada tabel 4, diketahui bahwa variabel impostor syndrome menunjukkan nilai sebesar 0.074 dengan $\mathrm{p}=0.033$ ( $>0.05$ ) yang berarti data impostor syndrome berdistribusi normal. Sedangkan variabel kecemasan akademis menunjukkan nilai sebesar 0.070 dengan $\mathrm{p}=0.056 \quad(\mathrm{p}>0.056)$ yang berarti data kecemasan akademis berdistribusi normal.

Sementara uji linieritas yang dilakukan dengan uji $\mathrm{F}$, diperoleh nilai $\mathrm{F}$ sebesar 0.727 dengan nilai signifikansi sebesar $0.872 \quad(\mathrm{p}>0.05)$ yang berarti variabel impostor syndrome memiliki hubungan yang linier dengan kecemasan akademis.

\section{Uji Hipotesis}

Pengujian hipotesis dalam penelitian ini dilakukan dengan menggunakan SPSS 22.00 for windows dengan teknik analisis regresi sederhana. Berdasarkan hasil analisis regresi memperoleh nilai $\mathrm{F}$ sebesar 33.582 dengan hasil signifikansi sebesesar $0.0001 \quad(\mathrm{p}<0.05) \quad$ sehingga dapat disimpulkan bahwa Ho ditolak. Effect Size yang terdapat pada penelitian ini adalah (r) $=0.419 \quad(\mathrm{r}>0.50)$ merupakan Medium Effect. Sedangkan total varian yang dapat dijelaskan oleh effect jika dilihat dari nilai $R$ square adalah sebesar 0.175 atau sebesar 17.5\%. Dari hasil analisis Bayes Factor diperoleh nilai BF10 sebesar 240.643.4. 
Berdasarkan hasil tersebut menunjukkan bukti yang tegas untuk mendukung hipotesis alternatif, sehingga impostor syndrome mampu menjadi prediktor yang signifikan terhadap kecemasan akademis pada mahasiswa baru.

\section{a. Analisis Tambahan}

Analisis tambahan ini digunakan untuk mengetahui kategori mahasiswa baru yang mengalami kecemasan akademis yang bersifat trait anxiety.

Tabel 5

Kategori Kecemasan Akademis (TraitAnxiety)

\begin{tabular}{cccc}
\hline $\begin{array}{c}\text { Kate- } \\
\text { gori }\end{array}$ & Norma & $\begin{array}{c}\text { Jum- } \\
\text { lah }\end{array}$ & $\begin{array}{c}\text { Persen- } \\
\text { tase }\end{array}$ \\
\hline Sangat & $\mathrm{X} \leq 23$ & 10 & $6.25 \%$ \\
Rendah & & & \\
Rendah & $23<\mathrm{X} \leq 29$ & 43 & $26.875 \%$ \\
Sedang & $29<\mathrm{X} \leq 36$ & 99 & $61.875 \%$ \\
Tinggi & $36<\mathrm{X} \leq 42$ & 14 & $8.75 \%$ \\
Sangat & $42<\mathrm{X}$ & 4 & $2.5 \%$ \\
Tinggi & & & \\
\hline Total & & 160 & $100 \%$ \\
\hline
\end{tabular}

Berdasarkan tabel 5 diketahui 18 subyek penelitian yang memiliki trait anxiety dengan presentase sebesar $11.25 \%$. Hasil tersebut diambil dari jumlah subyek yang masuk dalam kategori tinggi sebanyak $14(8.75 \%)$ subyek dan kategori sangat tinggi sebanyak empat $(2.5 \%)$ subyek.

Analisis tambahan berikutnya digunakan untuk mengetahui hubungan antara impostor syndrome dengan kecemasan akademis yang bersifat trait anxiety. Dari hasil analisis regresi menunjukkan hubungan yang signifikan antara impostor syndrome dan trait anxiety dengan hasil signifikansi $0.0001(\mathrm{p}<0,05)$ dan koefisien korelasi sebesar 0.433. Dengan nilai $R$ square sebesar 0.187 atau sebesar $18.7 \%$. Maka dapat diketahui bahwa impostor syndrome tidak hanya berhubungan dengan state anxiety namun juga dengan trait anxiety.

\section{DISKUSI}

Berdasarkan hasil penelitian menunjukkan bahwa impostor syndrome memiliki peran dalam mempengaruhi kecemasan akademis yang bersifat state anxiety pada mahasiswa baru, dengan nilai F sebesar 33.582 dengan tingkat signifikansi ( $p)$ sebesar $0.0001 \quad(p<0.05)$ yang berarti bahwa hipotesis pada penelitian ini diterima. Sehingga dapat dikatakan bahwa impostor syndrome berperan positif terhadap kecemasan akademis pada mahasiswa baru.

Hasil pengujian statistik penelitian ini sesuai dengan hasil penelitian dari Oriel, Plane, dan Mundt (2004) bahwa impostor syndrome berkorelasi positif dengan kecemasan. Hasil pengamatan klinis yang dilakukan oleh Clance (1985) mengungkapkan bahwa tingginya tingkat kecemasan, depresi, dan ketidakpuasan di kehidupannya, mendorong seorang impostor untuk mencari bantuan profesional (Sakulku \& Alexander, 2011). Melihat kategorisasi dari impostor syndrome terdapat $63 \quad(39.35 \quad \%)$ mahasiswa baru yang termasuk impostor . Penelitian terdahulu yang dilakukan pada sampel mahasiswa, menunjukkan hasil yang tidak jauh berbeda, seperti penelitian Wulandari dan Tjundjing (2007) menunjukkan 37 (29.8\%) dari 124 subyek tergolong impostor. Clance dan Imes (1978) menyatakan bahwa banyak dari klien mereka yang mengeluhkan perasaan sebagai impostor ketika mereka memasuki peranan baru. Hasil penelitian yang 
dilakukan oleh Harvey (1981) menunjukkan hubungan korelasi antara skor impostor dengan jumlah tahun mahasiswa di sekolah ( Chae, Piedmont, Estadt,\& Wicks, 1995). Hal tersebut juga didukung oleh hasil penelitian yang dilakukan oleh Chae, Piedmont, Estadt, dan Wicks (1995) terdapat korelasi yang negatif antara usia dan impostor syndrome. Maka mahasiswa yang berada pada tahun pertama memiliki perasaan sebagai impostor lebih tinggi dari pada siswa yang sudah berada pada tahun ke empat. Hal ini menunjukkan bahwa sebagian mahasiswa baru memiliki keraguan atau ketidakpercayaan terhadap kemampuan yang mereka miliki.

Perubahan peran dan lingkungan akademis memiliki pengaruh besar terhadap timbulnya impostor syndrome pada mahasiswa baru. Ketika mereka memasuki lingkungan universitas, mereka melihat kemampuan yang berbeda-beda Saat itulah perasaan rendah diri terhadap kemampuan yang dimiliki muncul dan mereka akan mempertanyakan lagi kemampuan yang mereka miliki. Impostor syndrome dapat terjadi pada individu yang belum memiliki keakraban dengan peran atau posisi mereka yang baru, adanya persaingan, adanya isolasi dalam pendidikan yang lebih tinggi, dan tekanantekanan lain yang sering ditemukan dalam budaya akademik lainnya (Zorn, 2005).

Pada tabel pengkategorian kecemasan menunjukkan bahwa 37 $(23.15 \%)$ subyek mengalami kecemasan akademis . Kecemasan akademis mengacu kepada terganggunya pola pemikiran dan respon fisik serta perilaku karena kemungkinan performa yang ditammpilkan siswa tidak diterima secara baik ketika tugas-tugas akademis diberikan (Ottens, 1991). Tekanan akademis, penyesuain diri dan ekspektasi yang tidak realistis memicu munculnya suatu kecemasan (Mahajan, 2010; Lallo, Kandou, \& Munayang, 2013).

$$
\text { Hasil pengujian hipotesis }
$$
menunjukkan nilai signifikansi 0.0001 $(\mathrm{p}<0.05)$ bahwa terdapat peran impostor syndrome dalam menjelaskan kecemasan akademis pada mahasiswa baru. Dimana impostor syndrome berperan dalam memunculkan kecemasan akademis yang dialami oleh mahasiswa baru sebesar 17.5 $\%$. Sedangkan $82.5 \%$ dipengaruhi oleh faktor lain seperti threat (ancaman), conflict (pertentangan), fear (ketakutan), unmet needs (kebutuhan yang tidak terpenuhi) ( Shohib, 2005; Mutmainna, 2014).

Hasil pengukuran kecemasan yang dilakukan dengan menggunakan alat ukur skala STAI (bagian TAI) terlihat bahwa impostor syndrome tidak hanya menunjukkan hubungan yang signifikan terhadap kecemasan state anxiety tetapi juga berhubungan signifikan dengan trait anxiety. Hal tersebut sejalan dengan hasil penelitian terdahulu yang dilakukan oleh Oriel, Plane, dan Mundt (2004) bahwa impostor syndrome berhubungan positif dengan kecemasan, baik state anxiety maupun trait anxiety. Topping (1983) menemukan korelasi positif yang kuat antara impostor syndrome dan trait anxiety. Dimana individu yang memiliki perasaan sebagai impostor cenderung individu-individu yang mengalami kecemasan dalam banyak situasi (Langford \& Clance, 1993).

Mahasiswa yang mengalami perasaan sebagai impostor, ketika mereka meraih suatu prestasi atau pencapaian hal itu akan menimbulkan suatu ketakutan dan kekhawatiran, dimana mereka menganggap bahwa kemampuan yang 
mereka miliki tidak layak untuk memperoleh suatu pencapaian maupun prestasi. Individu yang memiliki perasaan sebagai impostor menunjukkan skor yang tinggi untuk menjadi cemas, depresi, emosi tidak stabil, rentan terhadap tekanan psikologis dan efek negatif lainnya (Chae, Piedmont, Estadt, \& Wicks, 1995).

Perasaan sebagai impostor dapat meningkatkan kecemasan yang dialami oleh mahasiswa baru karena seorang impostor takut mengalami suatu kegagalan. Menurut Clance (dalam sakulku \& Alexander, 2011) seorang impostor membuat kesalahan dan tidak menunjukkan performa dengan standar tinggi, mereka akan menimbun perasaan malu dan terhina. Mereka akan menjebak diri sendiri ke dalam kegelisahan dengan mengangap semua yang dilakukannya adalah salah sehingga memicu munculnya suatu kecemasan. Individu yang mengalami kecemasan dalam akademis akan menunjukkan perilaku yang menghindar karena mereka menggap bahwa performa mereka belum sempurna. Mereka akan berusaha dengan keras untuk mengerjakan tugas dengan cermat untuk menghindari kesalahan (Ottens, 1999). Menurut Langford dan Clance (1993) individu yang mengalami impostor biasanya memiliki keinginan yang kuat untuk terlihat pintar dalam bidang akademik, akan tetapi mereka justru mengalami ketakutan saat menghadapi kesulitan dalam proses belajarnya, sehingga mereka akan mengalami kelelahan emosional, kehilangan motivasi, prestasi yang buruk, perasaan bersalah dan malu tentang keberhasilan, dan diperkuat oleh pengulangan siklus impostor (Clance \& Imes, 1978).

\section{KESIMPULAN}

Hasil analisis regresi linier sederhana antara impostor syndrome dengan kecemasan akademis menunjukkan hubungan yang signifikan, sehingga impostor syndrome mampu dalam menjelaskan kecemasan akademis pada mahasiswa baru. Sumbangan efektif variabel impostor syndrome terhadap kecemasan akademis pada mahasiswa baru sebesar $17.5 \%$ dan $82.5 \%$ dipengaruhi oleh faktor lain seperti threat (ancaman), conflict (pertentangan), fear (ketakutan), unmet needs (kebutuhan yang tidak terpenuhi). Berdasarkan hasil analisis tambahan diketahui bahwa impostor syndrome tidak hanya berhubungan dengan kecemasan akademis yang bersifat state anxiety tetapi juga dengan trait anxiety.

\section{DAFTAR PUSTAKA}

Chae, J.H., Piedmont, R.L., Estadt, B.K., \& Wicks, R.J. (1995). Personological evaluation of Clance's impostor phenomenon scale in a Korean sample. Journal of Personality Assessment. 6 (3), 468-485. doi: 10.1207/s1532775jpa6503_7

Clance, P.R., \& Imes, S. (1978). The impostor phenomenon in high achieving women dynamics and therapeutic intervention. Psychotherapy Theory, Research and Practice, 15 (3), 1-8. Diunduh dari

http://www.paulineroseclance.com/ pdf/ip_high_achieving_women.pdf

Clance, P.R., \& O'Toole, M.A. (1988). The impostor phenomenon: an internal barrier to empowerment 
and achievement. Women and Therapy, 6 (3), 51-64. Diunduh dari http://paulineroseclance.com/pdf/ip_internal_barrier_to_empwr mnt_and_achv.pdf

Clark, M., Vardeman, K., \& Barba, S. (2014). Perceived inadequacy: a study of the impostor phenomenon among college and research librarians. College and Research Libraries, 75 (3), 255-271. doi: $10.5860 /$ crl12-423.

Lallo, D.A., Kandou, L.F.J, \& Munayang, H. (2013). Hubungan kecemasan dan hasil UAS-1 mahasiswa baru fakultas kedokteran universitas Sam Ratulangi Manado tahun ajaran 2012/2013. E-Journal: Fakultas Kedokteran Universitas Sam Ratulangi. Diunduh dari : http://ejournal.unsrat.ac.id/index.ph p/eclinic/article/viewFile/3283/282 $\underline{7}$

Langford, J., \& Clance, P.R. (1993). The impostor phenomenon: recenr research findings regarding dynamics, personality and family patterns and their implications for treatment. Psychotherapy, 30 (3), 496-501). Diunduh dari . http://www.paulineroseclance.com/ pdf/-Langford.pdf

Mutmainna. (2014). Keyakinan diri dengan kecemasan dalam menghadapi pertandingan pada atlit beladiri Tae kwon do. Jurnal Online Psikologi, 2 (2), 239 - 255. Di unduh dari : http://ejournal.umm.ac.id

Ottens, A.J. (1991). Copping with Academic Anxiety. New York: The Rosen Publingsing Group.

Oriel, K., Plane, M.B., \& Mundt,M. (2004). Family medicine resident and the impostor phenomenon. The Department of Family Medicine, University of Wisconsin, 36 (4), 248-252. Diunduh dari : https://www.stfm.org/fmhub/fm200 4/April/Kathy248.pdf

Sakulku, J., \& Alexander, J. (2011). The impostor phenomenon. International Journal of Behavioral, 6 (1), 73-92. Diunduh dari:.http://bsris.swu.ac.th/journal/i 6/6-6_Jaruwan_73-92.pdf.

Vitasari, P., Wahab, M.N.A., Othman,A., Herawan, T., Sinnadurai, S.K. (2010). The relationship between study anxiety and academic performance among enginerring students. Procedia Social and Behavioral Science, 8, 490-497. Diunduh dari http://www.sciencedirect.com/scien ce/article/pii/S1877042810021725

Wulandari, A.D., \& Tjundjing, S. (2007). Impostor phenomenon, self-esteem, dan self-efficacy. Anima, Indonesian Psychological Journal, 23 (1), 63-73. Diunduh dari: http://digilib.mercubuana.ac.id/man ager/file_artikel_abstrak/Isi_Artike 1928094616273.pdf

Zorn, D. (2005, August). Academic culture feeds the impostor phenomenon. Leaders : The Newsletter for Academic Deans and Departement Chairs, 21 (8). Diunduh dari : http://www.yorku.ca/zorn/files/Aca demicLeader.pdf 